\title{
Pengkategorian Identiti dalam Iklan Peribadi: Kajian Representasi Gender Berasaskan Korpus
}

\section{(Gender and Identity Categorizations in Personal Advertisements: A Corpus -Based Study)}

\author{
Kesumawati A. Bakar1*iD \\ 1Pusat kajian Bahasa dan Linguistik, Fakulti Sains Sosial dan Kemanusiaan, Universiti Kebangsaan \\ Malaysia (UKM), 43600, Bangi, Selangor, Malaysia. \\ Email: kesuma@ukm.edu.my
}

\section{CORRESPONDING \\ AUTHOR (*): \\ Kesumawati A. Bakar \\ (kesuma@ukm.edu.my) \\ KATA KUNCI: \\ Femininiti \\ Maskuliniti \\ Linguistik Sistemik Fungsional \\ ATTITUDE \\ Pengkategorian Pelaku Sosial}

\section{KEYWORDS:}

Femininity

Masculinity

Systemic Functional Linguistics

ATTITUDE

Social Actor categorization

\section{CITATION:}

Kesumawati A Bakar. (2022).

Pengkategorian Identiti dalam Iklan

Peribadi: Kajian Representasi Gender

Berasaskan Korpus. Malaysian Journal of

Social Sciences and Humanities (MJSSH),

7(2), e001300.

https://doi.org/10.47405/mjssh.v7i2.1300

\begin{abstract}
ABSTRAK
Iklan peribadi menyediakan data yang ideal bagi mengkaji konstruksi identiti dan gender. Ciri-ciri identiti yang dipilih dan ditonjolkan dalam iklan peribadi memberi gambaran idealis personaliti dan tingkah laku individu yang mencari pasangan dalam pelbagai jenis masyarakat dan budaya yang berlainan. Kajian ini meneliti gabungan pengkategorian identiti dengan ekspresi penilaian ATTITUDE dalam penghasilan identiti gender maskulin dan feminin dalam iklan peribadi pengiklan lelaki dan wanita di Malaysia. Dengan menggunakan pendekatan analisis wacana dan teknik korpus linguistik, kajian ini memperlihatkan konstrual identiti gender sebagai satu interaksi kompleks pengkategorian identiti dan himpunan sumber penilaian ATTITUDE dalam teks. Pola lazim identiti gender yang tipikal dan tidak tipikal terhasil dengan membandingkan kategori struktur dan semantik deskripsi pengiklan. Penyataan-I dan kumpulan nominal membentuk titik permulaan analisis dan pola linguistik diklasifikasikan secara semantik mengikut kategori ATTITUDE dari kerangka teori Appraisal dan kerangka Pengkategorian Pelaku Sosial. Dapatan kajian menunjukkan bahawa orientasi pengiklan terarah kepada permintaan bakal pasangan dalam konteks pemilihan pasangan hidup. Pengiklan didapati menghasilkan konstruksi identiti yang selari dengan apa yang dicari oleh lelaki dan wanita secara umum, sebagai contoh 'wanita penyayang' dan 'lelaki berjaya dan stabil kewangan'. Di samping itu, dapatan kajian juga menemukan representasi identiti Malaysia sebagai 'a simple person' atau 'seorang yang sederhana' yang melangkaui batasan gender. Kajian ini menyumbang kepada bidang gender dan linguistik dengan mengenal pasti kategori dan interaksi fitur linguistik femininiti dan maskuliniti melalui analisis berasaskan korpus iklan peribadi.
\end{abstract}




\begin{abstract}
Personal ads website is an ideal site for examining the construction of identities. Salient preferences emerge in the selection of traits and identity categories and accordingly, these advertisements provide insights into advertisers' idealizations of self-identities in different societies and cultures. This study examines gender identity representations in the discourse of 200 online personal advertisements by Malaysian men and women. Using a combination of corpus linguistic techniques and discourse analysis, this study examines the ways in which feminine and masculine identities are construed as a result of a complex interaction of identity categorization and evaluative resources in the descriptions. I-Statement and Nominal group form two points of entry for analysis and common features are semantically classified according to ATTITUDE from the Appraisal framework and Social Actor categorization. Findings showed that advertisers appear to orient to what is expected in the context of courtship initiation, and are found to produce socially specific verbal practices that correspond to stereotypical constructions of gender identity such as 'an affectionate woman' and 'a successful and financially stable man'. More significant, however, is the construal of a Malaysian identity type that is commonly tendered and that transcends gender boundary 'a simple person'. This study is a contribution to scholars working in the area of gender identity and linguistics as it identifies linguistic realizations of femininities and masculinities and demonstrates the interaction of the linguistic features through a corpus-based analysis of personal ads.
\end{abstract}

Sumbangan/Keaslian: Kajian ini adalah salah satu daripada kajian yang telah menyiasat pengkategorian identiti verbal melalui deskripsi perlakuan, pemikiran dan ekspresi penilaian ATTITUDE dalam membina pelbagai tema diskursif yang membentuk representasi identiti gender maskulin dan feminin yang pelbagai dalam iklan peribadi dalam talian.

\title{
1. Pengenalan
}

Peningkatan populariti iklan peribadi dalam kalangan individu yang mencari pasangan telah mendorong kajian dalam bidang sains sosial, kemanusiaan dan juga sains komputer (Baker, 2006; Kesumawati, 2016; Fong \& Nyathi 2019; VanderStouwe 2019). Dapatan kajian-kajian sebelum ini telah memberikan gambaran dan pemahaman tentang pelbagai isu gender berkaitan dengan amalan sosial dan budaya, penggunaan bahasa dan juga hubungan kekuasaan dalam masyarakat. Lebih 30 tahun, penyelidik sains sosial telah menggunakan iklan peribadi untuk mengkaji representasi identiti pengiklan, apa yang dicari dan dikehendaki oleh mereka daripada pasangan. Salah satu penemuan terawal kajian dalam bidang ini menunjukkan bahawa kecenderungan pengiklan dalam membuat permintaan adalah kongruen dengan stereotaip gender (Cameron et al., 1977). Sebagai contoh, wanita lebih kerap menyatakan minat terhadap lelaki yang mempunyai ciri kewangan yang kukuh, sensitif dan juga lucu. Lelaki pula lebih berminat untuk mencari pasangan yang cantik, peramah dan penyayang dari segi 
perlakuan. Dalam kes ini, iklan peribadi digunakan untuk mengukur tahap kebolehinginan (desirability) sifat-sifat tertentu. Penemuan secara amnya menunjukkan bahawa ciri-ciri fizikal pada umumnya lebih penting daripada ciri-ciri keperibadian kepada lelaki berbanding wanita (Downing, 2013).

Kajian ini meneliti konstruksi identiti feminin dan maskulin pengiklan Malaysia dalam iklan peribadi dalam talian match.com dengan menggunakan kombinasi analisis wacana berasaskan korpus bersama kerangka pengkategorian Pelaku Sosial (Social Actor) (Van Leeuwen, 2008) dan sistem ATTITUDE (Martin \& White, 2005). Penggunaan kata nama dan kata ganti dalam wacana iklan peribadi (Marley, 2000; Baker, 2003) kerap dikaji dalam disiplin gender dan linguistik, namun kajian yang mengungkap interaksi kompleks pengkategorian identiti dan ekspresi ATTITUDE dalam pembinaan identiti gender tidak banyak dilakukan oleh penyelidik lepas (Kesumawati, 2014; 2015). Makalah ini bertujuan untuk menjelaskan pengkategorian identiti tekstual melalui deskripsi perlakuan, pemikiran dan ekspresi penilaian ATTITUDE dalam membina pelbagai tema diskursif yang seterusnya membentuk representasi identiti gender maskulin dan feminin berbeza di my.match.com. Dengan itu analisis dilakukan untuk mencari jawapan bagi persoalan kajian berikut:

i. Apakah pengkategorian identiti dan fitur penilaian ATTITUDE yang digunakan dalam pembentukan identiti gender dalam talian?

ii. Apakah tema diskursif identiti gender maskulin dan feminin yang terbentuk dari interaksi pengkategorian identiti Pelaku Sosial dan ATTITUDE?

Pada sub-bahagian seterusnya, artikel ini akan meringkaskan tinjauan literatur kajian lepas mengenai teori identiti dan gender, diikuti dengan penjelasan konsep maskuliniti dan femininiti, dan seterusnya iklan peribadi. Kemudian sub-bahagian berikutnya pula mempersembahkan data dan metodologi, sebelum diakhiri dengan hasil kajian dan perbincangan representasi tekstual identiti maskulin, feminin dan bangsa Malaysia dalam iklan peribadi atas talian.

\section{Tinjauan Literatur}

\subsection{Identiti dan Gender}

Konsep identiti merupakan konsep yang luas dan bersifat subjektif. Pendefinisian konsep ini telah lama menjadi subjek perdebatan dalam kalangan ahli teori esensialis dan pascaskrukturalis. Dalam abad ke-18, iaitu era Enlightement, identiti difahami sebagai individu yang berautonomi yang didorong oleh pemikiran, pengalaman dan pengetahuan rasional. Teori Romantic expressivism yang muncul di awal abad ke-19 melihat identiti sebagai entiti yang didorong oleh moral, perasaan dan emosi (Benwell \& Stokoe, 2006). Pada akhir abad ke-20, identiti difahami sebagai individu sosial hasil daripada perpindahan sempadan geografi dan pertukaran pengalaman di ruang siber. Identiti individu sosial pada zaman moden mencari persamaan dengan individu yang lain melalui perlakuan dan percakapan, seterusnya menghasilkan kehomogenan yang disebut sebagai identiti sosial (Tajfel \& Turner, 2004) atau identiti kolektif (Benwell \& Stokoe 2006). Pada masa yang sama, manusia juga komited dalam membezakan diri mereka dari individu yang lain dalam aspek emosi, moral, mental dan sebagainya (Woodward, 2004). Sepanjang abad 18 hingga ke 20, ideologi dan pendekatan yang berlainan di dalam konseptualisasi identiti telah menghasilkan teori-teori yang dicirikan oleh dikotomi - dalaman berbanding luaran, peribadi berbanding sosial dan asas 
berbanding dinamik. Walaupun demikian, dikotomi ini boleh dilaraskan oleh teori pascastrukturalis.

Teori pascastrukturalis mengusulkan pemahaman alternatif mengenai identiti yang dikembangkan oleh Butler (1996) sebagai perlakuan yang diulang-ulang (performativiti) hingga terbentuk "identiti yang tetap".

"Gender is the repeated stylization of the body, a set of repeated acts within a highly rigid regulatory frame that congeal over time to produce the appearance of substance, of a natural sort of being." Butler (1996)

Butler (1996) menyatakan bahawa identiti dibentuk secara performatif dan perkara ini dinyatakan dalam bukunya yang berjudul Gender Trouble. Penekanan kini adalah pada aspek perlakuan identiti yang berunsur diskursif. Perlakuan diskursif merujuk bukan sahaja kepada bahasa yang kita gunakan, tetapi juga cara lain mengekspresikan diri, contohnya melalui pakaian, bahasa tubuh, mimik muka, muzik dan sebagainya.

\subsection{Perlakuan Gender}

Penelitian gender dalam makalah ini menggunakan Teori Performativiti yang dikembangkan oleh Butler (1990). Teori ini melihat gender sebagai konsep fluid atau luwes yang terbentuk melalui perlakuan diskursif secara berterusan dan berulang-ulang sebagai seorang lelaki atau wanita, yang menepati norma-norma budaya dan sosial sesebuah masyarakat dan keadaan persekitaran individu tersebut. Butler (1990) menyatakan bahawa gender bukanlah sesuatu yang dianggap kekal wujud seperti sebuah ciri intrinsik, tetapi terhasil melalui perlakuan dan kesannya (Breen et al., 2001). Butler (1990) juga mempertikaikan tanggapan intrinsik yang mengaitkan biologi dan jantina dengan identiti gender sebenar, dan menyatakan bahawa identiti gender semula jadi tidak wujud. Pemahaman ini membentuk asas teori Butler (1990) mengenai identiti gender yang bertentangan dengan pemahaman gender sebagai satu kategori entiti yang stabil. Identiti gender mengikut teori performativiti merupakan satu konstruksi sosial yang fleksibel yang terbuka kepada adaptasi dan berubah mengikut perlakuan diskursif seseorang.

\subsection{Perlakuan Identiti Feminin dan Maskulin}

Identiti berdasarkan pengenalpastian seseorang sebagai lelaki atau wanita mengikut tuntutan dan kepercayaan masyarakat diistilahkan sebagai femininiti dan maskuliniti. Maskulin ialah ciri-ciri lazim seorang lelaki manakala feminin merujuk kepada ciri-ciri lazim seorang wanita. Secara umum, maskulin merujuk kepada seseorang yang memiliki sifat-sifat kejantanan dari segi keperibadian, emosi, perlakuan (sebagai contoh agresif dan dominan) pekerjaan (contohnya mekanik) dan minat (contohnya bertinju dan bermotorsikal) (Radzi et al., 2018). Sebaliknya, feminin merujuk kepada tingkah laku, emosi, pekerjaan, minat yang memenuhi sifat-sifat keperempuanan seperti perwatakan yang lembut, lebih beremosi dan sensitif, meminati perawatan wajah dan tubuh serta aktiviti menyulam. Dalam kajian ini, femininiti dan maskuliniti diterjemahkan sebagai identiti gender yang merujuk kepada sejauh mana individu melihat diri mereka sebagai maskulin atau feminin (Stets \& Burke, 2000).

Dua jenis representasi maskuliniti yang tipikal dan dominan ialah lelaki sebagai pencari nafkah untuk keluarga, atau seorang yang atletik, cergas dan bergaya (Baker, 2003; 
Parker \& Stepler, 2017), manakala representasi tipikal femininiti ialah wanita bersikap emosional dan penyayang atau langsing dan cantik (Williams, 2007; Kim \& Lee, 2018). Dalam mana-mana komuniti, perlakuan feminin dan maskulin yang tipikal dilihat sebagai perlakuan normatif yang dilabel sebagai maskuliniti dan femininiti hegemonik (Connell \& Messerschmidt, 2005; Garcia-Gomez, 2020). Walau bagaimanapun, kelainan dalam keperibadian, iaitu dari segi tingkah laku, emosi dan sikap setiap individu lelaki dan wanita secara semula jadinya telah membawa kepada konstruksi maskuliniti dan femininiti yang pelbagai (Bordo, 1999; Baker, 2008; Hashim et al, 2011; Aboim, 2016; Radzi et al., 2021).

\subsection{Konstruksi Identiti dalam Iklan Peribadi}

Iklan peribadi menyediakan data yang ideal bagi kajian konstruksi identiti dan gender. Ciri-ciri kategori identiti yang dipilih dan yang ditonjolkan dalam iklan, contohnya sifat fizikal, perlakuan, emosi dan minat memberi gambaran idealis pengiklan diri dan tingkah laku individu dari pelbagai jenis masyarakat dan budaya dalam pencarian pasangan hidup (Coupland, 1996; Baker, 2003; Gama e Silva, 2007). Deskripsi identiti yang padat, yang terhasil dari kekangan ruang dan perkataan dalam kedua-dua jenis iklan bertulis dan dalam talian, membentuk satu ciri tersendiri iklan peribadi. Gambaran identiti ini lazimnya dicirikan menerusi rentetan kata sifat dan kata nama (Bruthiaux, 1994) seperti contoh di bawah.

I am a single lady, sensual, cool, attractive, romantic and a good looking girl...

(Saya wanita bujang, sensual, kool, menarik, romantik dan cantik)

I am a friendly, understandable and straight forward person, but sometimes I am pretty talkative, stubborn and hot temper.

(Saya seorang yang peramah, memahami dan lurus, tetapi kadangkadang saya banyak mulut, keras kepala dan panas baran.)

Coupland (1996) meneliti kata nama dan kata sifat yang membentuk sifat-sifat klasifikasi gender (cth. wanita bujang, duda), umur (cth. 33 tahun), penampilan (cth. tinggi, cantik), minat (cth. mendengar muzik, menonton filem) dan kerjaya (cth. pengarah syarikat) dalam datanya. Dapatan kajian beliau menunjukkan gambaran identiti yang berasaskan stereotaip sosial tentang belia, femininiti, maskuliniti, daya tarikan, dan lain-lain (Coupland, 1996: 194). Shalom (1997) juga mendapati bahawa, tanpa mengira gender dan seksualiti, wacana gender hegemonik dikekalkan melalui pelbagai cara; Sebagai contoh, penampilan fizikal yang menarik dicari oleh lelaki, manakala wanita lazimnya memilih lelaki yang berkerjaya. Dua perkara berkaitan dengan kajian ini adalah yang pertama, sifat-sifat itu diwujudkan melalui kata nama dan kata sifat yang disebut sebagai kumpulan nominal, dan kedua, kekerapan dan pola sifat ini membezakan pelbagai jenis identiti dan memperlihatkan pilihan lelaki dan wanita dalam pemilihan pasangan hidup. Oleh itu, kumpulan nominal menjadi struktur pertama atau titik permulaan bagi kajian gender dan identiti dalam iklan peribadi ini.

Penggunaan klausa penyataan-I (I-statement) juga penting dalam kajian ini kerana ia membentuk struktur kedua paling kerap digunakan oleh lelaki dan wanita dalam deskripsi iklan mereka contohnya I love the beach (Saya gemarkan pantai) dan I travel extensively (Saya kerap melancong). Kedudukan awal I dalam klausa memberi 
keutamaan tematik kepada penulis dan merupakan fitur diskursif lazim dalam menjalinkan perhubungan awal antara pengiklan dan pembaca.

\subsection{Kata ganti nama diri pertama 'I' dalam iklan peribadi}

Penggunaan I atau saya sangat ketara dalam korpus kajian ini berdasarkan pada frekuensi I yang tinggi dalam data, seterusnya menjadikan perkataan ini sebagai fitur analisis kedua yang lazim digunakan oleh pengiklan dalam gambaran tekstual mereka. Kedudukan awal I dalam klausa memberikan penekanan tematik kepada penulis dan mewujudkan proksimiti antara pengiklan dan pembaca. Analisis terperinci menunjukkan pola dan tema semantik yang berkaitan dengan identiti feminin dan maskulin dari segi tingkah laku, emosi dan atribut. Sebagai contoh, menerusi pernyataan I objek kebahagiaan lelaki dan wanita boleh dipaparkan dengan menyatakan minat bersantai. Ketika perasaan positif diungkapkan, pengiklan membuat pengkategorian sosial yang berbeza berdasarkan aktiviti riadah.

I enjoy movies (Saya minat menonton filem)

I like computer, tech stuff and books (Saya minat komputer, barangan teknologi dan buku)

I love the outdoors (I suka berada di luar rumah)

Untuk mengkaji representasi identiti, dua konsep analisis wacana dari kerangka analisis Pelaku Sosial (Van Leeuwen, 2008) dan ATTITUDE dari kerangka Appraisal (Martin \& White, 2005) digunakan dalam subklasifikasi semantik pernyataan-I dan kumpulan nominal.

\subsection{Pengkelasan Identiti dalam Iklan Peribadi}

Kerangka Pelaku Sosial (Van Leeuwen, 2008) boleh dibahagikan kepada dua kategori Fungsionalisasi dan Identifikasi. Van Leeuwen (2008) berpendapat bahawa dua kategori ini boleh membantu kajian ungkapan lisan dan bertulis dalam menjawab persoalan Siapa awak? Siapa kita? Siapa dia? dan Siapa mereka?

Fungsionalisasi dapat menentukan identiti individu menerusi aktiviti dan perbuatan yang dilakukan, sebagai contoh pekerjaan (pemuzik) atau peranan sosial (sebagai contoh, jurucakap) (Van Leeuwen, 2008). Selain dari pekerjaan, data dari kajian ini juga menunjukkan satu lagi subset peranan dan aktiviti yang kerap digunakan dalam data kajian ini, iaitu peranan masa lapang (cth. pengembara dan seorang yang gemar melihat barang di kedai (a traveller and a window-shopper) dan aktiviti masa lapang (cth. Saya boleh bersalsa sedikit (I can salsa a little) (Kesumawati, 2014). Subset ini akan menjadi kategori tambahan kepada kategori fungsionalisasi Van Leeuwen (2008).

Kategori Identifikasi dapat menentukan identiti individu dari segi siapa mereka (Van Leeuwen, 2008). Ada tiga jenis subkategori identifikasi: Klasifikasi, identifikasi hubungan dan identifikasi fizikal. Klasifikasi merujuk kepada kategori seperti umur, jantina, asal-usul, bangsa, etnik, agama, orientasi seksual dan sebagainya. Identifikasi hubungan ialah identifikasi melalui hubungan perseorangan, kekeluargaan atau hubungan kerja dengan individu lain seperti rakan, ibu bapa, saudara, adik, rakan sekerja dll. Identifikasi fizikal merujuk kepada ciri-ciri fizikal seseorang melalui kata 
sifat seperti tinggi, berotot, sihat atau frasa preposisional dengan with, contohnya I am tall, with a slim figure (Saya tinggi dengan badan yang langsing).

\subsection{Kerangka ATTITUDE}

ATTITUDE dari kerangka teori Appraisal (Martin \& White, 2005) adalah sistem makna interpersonal yang menawarkan kerangka analisis untuk mengenal pasti dan mengklasifikasikan ekspresi penilaian sikap dan emosi dalam data iklan peribadi secara sistematik. Fokus analisis sikap dalam kajian ini adalah pada ekspresi secara langsung dan tidak langsung emosi, penilaian tingkah laku dan penilaian entiti, prestasi dan fenomena semula jadi.

Ekspresi ATTITUDE boleh dikategorikan kepada 3 jenis - Affect (ekspresi emosi), Judgement (penilaian tingkah laku) dan Appreciation (penilaian sesuatu entiti/benda). Klasifikasi ATTITUDE ini akan dijelaskan menggunakan contoh dari korpus kajian bersama dengan konvensyen anotasi dari Martin dan White (2005) yang digunakan dalam analisis. Perbezaan pertama dibuat antara ungkapan yang bersifat atau bernilai positif [+] atau negatif [-]. Dalam contoh berikut, kata-kata dalam huruf tebal dinyatakan sebagai mewakili sifat positif atau negatif (ditunjukkan dalam tanda kurung).

I love [+] movies

(Saya suka [+] menonton filem)

I am talkative [+], stubborn [-] and hot temper [-]

(saya peramah [+], degil [-] dan panas baran [-]

\subsubsection{Affect}

Affect menggambarkan reaksi emosi positif atau negatif terhadap seseorang, sesuatu aktiviti atau perkara. Berikut merupakan contoh emosi positif dan negatif yang diambil dari data, dengan Affect dalam huruf tebal dan bergaris bawah.

I felt sad [-]

(saya merasa sedih)

I was confident $[+]$

(saya merasa konfiden [+])

\subsubsection{Judgement}

Judgement merujuk kepada penilaian peribadi atau penilaian moral terhadap sikap atau tingkah laku seseorang. Penilaian peribadi diklasifikasikan sebagai penilaian kenormalan, kemampuan dan kecekalan seseorang. Penilaian moral diklasifikasikan sebagai penilaian ketulusan, kesopanan dan etika seseorang (Martin \& White, 2005). Berikut adalah contoh penilaian Judgement positif dan negatif yang terdapat dalam data.

I am sincere [+], loyal $[+]$, truthful $[+]$, caring $[+]$, friendly $[+]$ person Saya seorang yang ikhlas $[+]$, setia $[+]$, jujur $[+]$, penyayang $[+]$, peramah $[+]$ 


\subsubsection{Appreciation}

Appreciation lazimnya melibatkan penilaian penampilan atau sifat fizikal, misalnya

I am a handsome [+] guy, and I am and will always be fat [- ]

Saya seorang yang tampan [+], dan saya dan akan sentiasa gemuk [-].

Appreciation juga boleh merujuk kepada tarikan, keseimbangan, dan nilai sesuatu perkara (Martin \& White, 2005). Sebagai contoh,

I think communication is a very important [+] element in a relationship. Saya rasa komunikasi adalah elemen yang sangat penting [+] dalam hubungan.

\section{Metod Kajian}

Korpus bagi kajian ini adalah 200 iklan peribadi my.match.com yang dimiliki warganegara Malaysia lelaki dalam lingkungan 22-36 tahun dan wanita dalam lingkungan 20-32 tahun. Korpus ini dibahagikan kepada 2 set 100 iklan peribadi berdasarkan gender, dengan token perkataan berjumlah 65,659, iaitu 31,899 bagi wanita dan 33,730 bagi lelaki. Data ini membentuk korpus khusus (Baker, 2009) yang digunakan bagi mengkaji konstruksi identiti gender dalam talian.

Gabungan metodologi kuantitatif dan kualitatif yang diguna pakai melibatkan gabungan korpus linguistik dan analisis wacana. Korpora teks diproses dan dianotasi menggunakan dua program perisian saling melengkapi yang dikenali sebagai Wordsmith (Scott, 2004) dan UAM Corpus Tool (O'Donnell, 2008) untuk pengenalpastian fitur linguistik dan pola penggunaannya dalam data. Wordsmith (Scott, 2004) digunakan untuk pengenalpastian 1) senarai perkataan (Wordlist) dan 2) kekerapan atau frekuensi penggunaannya dalam data. 30 perkataan teratas dalam senarai Wordlist memperlihatkan beberapa ciri-ciri lazim berkaitan representasi identiti dalam iklan peribadi. Sebagai contoh, 'simple' ialah sifat peribadi yang tipikal dan 'travel' ialah senarai aktiviti masa lapang yang kerap muncul dalam data. Memandangkan identiti direalisasikan oleh fitur linguistik yang berbeza (item leksikal, frasa atau klausa), ciriciri identiti dalam korpus juga dianotasi dan diklasifikasikan menggunakan UAM Corpus Tool berdasarkan kategori Pelaku Sosial (Van Leeuwen, 2008) dan kerangka pengkategorian ATTITUDE (Martin \& White, 2005). Sebagai contoh, "I am an expert in computer" dianotasi sebagai Fungsionalisasi melalui pekerjaan dan juga dianotasi sebagai penilaian positif Judgement. Setelah korpus dianotasi sepenuhnya, kekerapan setiap kategori Pelaku Sosial atau ATTITUDE boleh dijana. Sebagai contoh, Rajah 1 di bawah menunjukkan senarai 263 Affect positif yang tersurat dalam korpus wanita. Ini menunjukkan usaha pengiklan wanita untuk tampil positif dari segi emosi dalam perihalan identiti mereka.

Identiti terbentuk secara tekstual melalui pelbagai jenis penyataan-I dan kumpulan nominal kategori tingkah laku, emosi, sikap, pekerjaan dan aktiviti santai yang membentuk beberapa kluster diskursif seperti penampilan, pekerjaan dan pendidikan, emosi dan minat. Kluster-kluster diskursif ini berkombinasi dan seterusnya menghasilkan beberapa representasi identiti feminin dan maskulin pengiklan peribadi dalam talian yang berbeza. 
Rajah 1: Senarai 263 Affect positif dalam korpus pengiklan wanita

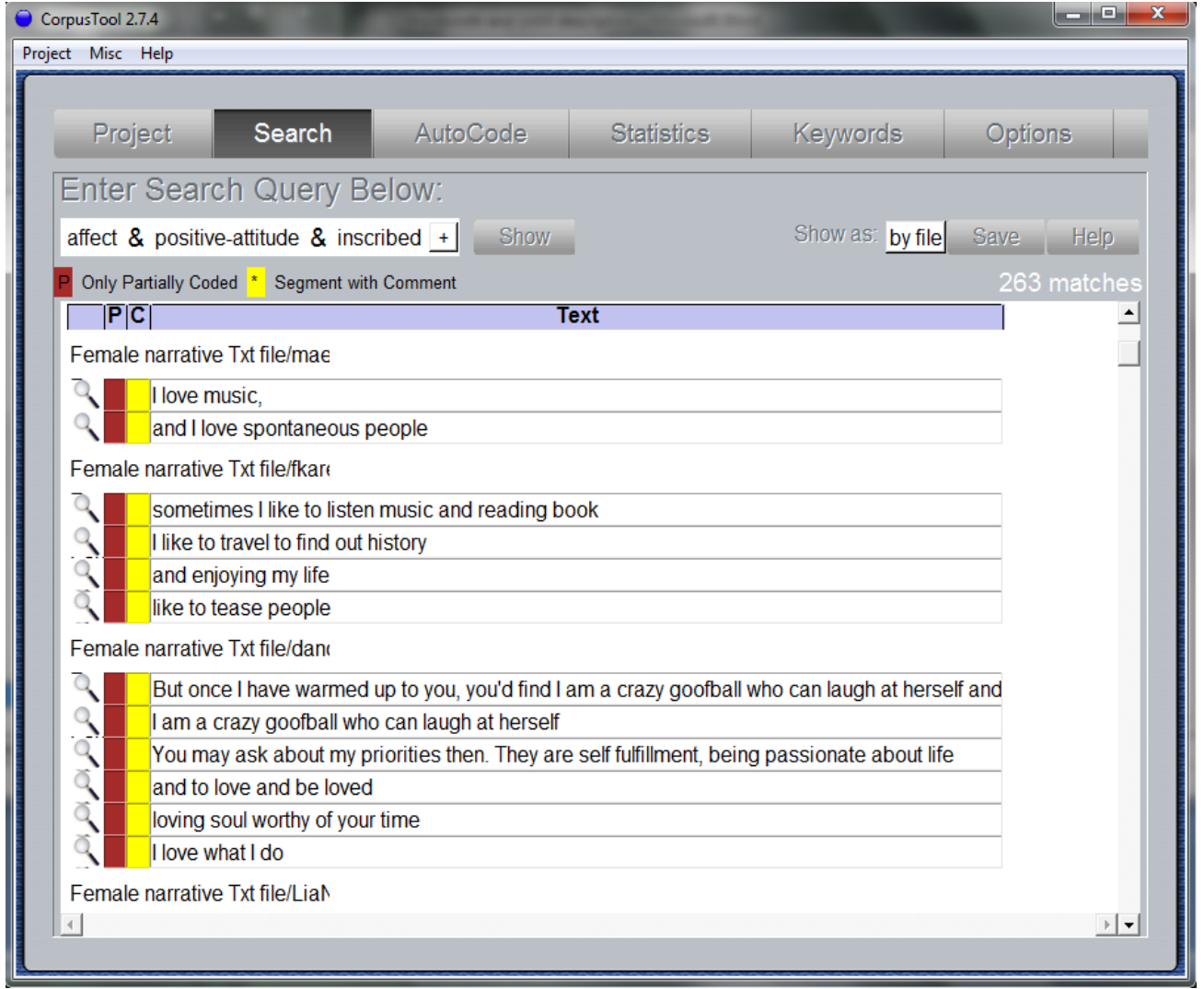

Perlakuan stereotaip maskulin dan feminin kerap muncul dalam analisis, sekaligus membentuk representasi identiti gender yang dominan atau tipikal dalam data. Secara keseluruhannya, berdasarkan pengkategorian semantik Pelaku Sosial dan ATTITUDE, pola nahu dan wacana yang terhasil dari analisis Wordsmith dan anotasi UAM Corpus Tool merealisasikan empat identiti tipikal dan tidak tipikal maskulin dan feminin, dan satu identiti Malaysia. Dua jenis identiti maskulin berdasarkan kekerapan pengkategorian identiti Pelaku Sosial dan ciri-ciri ATTITUDE adalah 1) Lelaki berjaya dan stabil kewangan dan 2) Lelaki sihat dan atletik. Dua jenis identiti feminin yang dominan yang terdapat dalam data wanita adalah 1) Wanita penyayang dan 2) Wanita Cemerlang dan Berjaya. Kesemua identiti ini dicirikan oleh pelbagai jenis kombinasi kluster diskursif 1) penampilan (cth. saiz badan, daya tarikan, kecergasan) 2) pekerjaan (cth pencapaian, aktiviti dan peranan) 3) emosi (cth. kebahagiaan dan keperibadian) 4) tingkah laku dan 5) minat (cth. sukan dan bersosial). Identiti Malaysia yang muncul berdasarkan pengelompokan ciri-ciri tingkah laku dan penilaian Judgement positif adalah 'a simple person' atau sorang yang sederhana. Dengan menggunakan teknik korpus linguistik, sumber tekstual ini merangkumi corak tingkah laku linguistik yang membentuk lima identiti maskulin, feminin dan Malaysia yang disebutkan di atas.

\section{Hasil Kajian dan Perbincangan}

\subsection{Maskuliniti dalam Ruang Iklan Peribadi Malaysia}

Dapatan analisis korpus mempamerkan penghasilan maskuliniti hegemonik melalui sifat fizikal, kekuatan kewangan dan pekerjaan. Dua tema maskulin utama yang muncul daripada dapatan analisis adalah wacana 1) pendidikan, pekerjaan dan kapasiti kewangan, dan 2) kekuatan dan kecergasan lelaki. Kedua-dua tema ini akan dijelaskan 
dalam sub-bahagian seterusnya. Pembentukan identiti ini didapati berkorelasi dengan identiti maskulin dalam kajian gender terdahulu (Morettini, 2016; Messerschmidt, 2019; Radzi et al., 2018; 2021).

\subsection{Lelaki Berjaya dan Stabil Kewangan}

Representasi lelaki berjaya dan stabil kewangan direalisasikan menerusi pelbagai fitur linguistik dan pola sosio-semantik dalam teks. Hasil kajian menunjukkan bahawa fungsionalisasi membentuk mod sosio-semantik yang dominan dalam mencirikan lelaki yang bekerjaya. Pengiklan menggunakan pengkategorian identiti melalui perlakuan dan peranan dalam pekerjaan. Terdapat sejumlah 64 contoh klausa fungsionalisasi pekerjaan yang lazimnya direalisasikan melalui kata kerja aktiviti dan perlakuan yang berkaitan. Bilangan kekerapan fungsionalisasi menunjukkan bahawa lelaki yang berkerjaya secara umumnya ditafsirkan sebagai pelaku aktiviti pekerjaan, seperti yang ditunjukkan dalam kenyataan berikut:

Membantu pelanggan dalam mengenal pasti objektif
korporat/keterikatan dan menyediakan strategi dan penyelesaian.
Sebenarnya saya banyak menghabiskan masa artikel teknikal dalam
talian setiap hari dan setiap pagi.
(Assist client in identifying corporate/engagement objectives and provide
strategy and solutions. Actually I spend a lot time reading online technical
article everyday and every morning.)

Jika keupayaan menyediakan keperluan keluarga merupakan satu ciri maskuliniti yang berjaya (Thebaud 2010; Radzi et al., 2018), maka lelaki berkerjaya yang berjaya boleh didefinisikan sebagai seorang yang mampu dan kompeten dari segi kewangan dan pekerjaan. Kontruksi ini terhasil dari konfigurasi linguistik yang melibatkan pola pemilikan, emosi dan Judgement positif tingkah laku. Analisis menunjukkan pendahuluan kata nama stable yang kerap digandingkan dengan kata nama kerjaya (stable career) dan pendapatan (stable income). Oleh itu, kata sifat stable merupakan kolokasi dua perkataan tersebut, mengkategorikan ia sebagai penilaian positif Judgement; dari segi kestabilan yang dinyatakan secara tidak langsung melalui kebergantungan dan jaminan hidup dan penilaian positif kesetiaan kepada sesuatu pekerjaan, dan keupayaan menyediakan keperluan pasangannya. Baker (2003) menyatakan bahawa secara tradisionalnya konsep pencari nafkah selalunya dikaitkan dengan ketua keluarga dan kewangan yang kukuh. Para pengiklan nampaknya mengundang penilaian Judgement positif yang menandakan keupayaan mereka sebagai seorang lelaki yang berjaya. Berikut merupakan contoh Judgement positif kewangan dan pekerjaan.

Saya ada pendapatan lebih, pekerjaan yang stabil...

(i have more income, a stable job...)

Saya berumur 30 tahun pada tahun ini, dengan kerjaya dan pendapatan yang stabil.

(I'm 30 this year, with a stable career and income.)

Seperti yang diperhatikan oleh Baker (2006) dan Radzi et al. (2021), manusia menunjukkan kejayaan peribadi dengan menggambarkan pekerjaan yang mereka lakukan, sama ada mereka berpelajaran tinggi, atau jenis kereta yang mereka pandu; 
kesemua ini didapati dalam sebahagian besar deskripsi identiti pengiklan lelaki. Contoh di bawah mempamerkan kejayaan peribadi dan sosial melalui kepelbagaian proses dan kumpulan nominal. Pemilikan objek material bukan saja digunakan berulang kali untuk menandakan kelayakan, pengalaman dan status (cth. jam tangan Omega) dan kejayaan (cth. ijazah sarjana) tetapi kedua fitur ini juga mengkategorikan para lelaki dalam kelas maskuliniti yang berjaya secara profesional.

Kereta saya, saya memandu kereta Altis. Komputer riba saya, ialah model Acer yang baru. Jam tangan saya... Omega Seamaster 2005.

(My car, I drive an Altis. My laptop, it's a new Acer model. My watch... Omega Seasmaster 2005).

Saya mempunyai pekerjaan impian bagi mereka yang diluar sana. Di mana semuanya dibayar...

(I have a dream job for many others out there. Where everything is paid for...)

Konsep solvensi juga berkaitan dengan kejayaan; Ianya satu ciri yang jarang disebut (yang menariknya hanya oleh lelaki) tetapi boleh menjadi pengisytiharan solvensi terang-terangan seperti I am financially stable (saya stabil dari segi kewangan). Solvensi terbentuk melalui 1) aktiviti pekerjaan seperti I have built a successful business, made my fortune there (saya telah membina perniagaan yang berjaya dan mengumpul kekayaan dari situ) dan 2) penerangan aktiviti santai seperti enjoy travelling and outdoor activities - current and past jobs afford me this lifestyle (suka melancong dan aktiviti luar rumah pekerjaan yang lepas dan terkini memberi saya gaya hidup sebegini). Para penyelidik sains sosial lazim menemui dapatan yang menunjukkan kepentingan status sosial, kebolehan mencari nafkah dan kesanggupan untuk berkongsi kejayaan dengan wanita, dikalangan lelaki yang mencari pasangan hidup (Dunn et al., 2010). Atribut yang dikaitkan dengan kemampuan seperti kecerdasan, kestabilan dan pendidikan tinggi berada di peringkat lima teratas bagi wanita (Lippa, 2007; Gilles \& Starbuck, 2018) dapat membantu untuk menerangkan kekerapan deskripsi pendidikan/profesional dan solvensi oleh lelaki dalam iklan mereka. Dapatan kajian ini memperlihatkan kepekaan sesetengah lelaki dalam menggambarkan ciri yang dihargai oleh wanita secara umum dalam iklan mereka.

Seterusnya, kejayaan bukan sahaja berkaitan dengan pencapaian atau paparan harta benda, tetapi juga semangat dan minat yang diluahkan terhadap pekerjaan. Lelaki berkerjaya juga menunjukkan Affect positif terhadap pekerjaan mereka melalui deskripsi kebahagiaan seperti contoh berikut.

Saya menyukai pekerjaan sekarang, mencabar.

(I love my current job, challenging.)

Saya suka pekerjaan saya kerana saya suka mengambil gambar yang cantik.

(I like my job because I like to take a nice picture.)

Bagaimana kejayaan dicapai dan bagaimana ia dikendalikan juga merupakan dua tema berbeza yang muncul dari analisis. Integriti dan dedikasi dalam kalangan lelaki berkerjaya diperlihatkan melalui penilaian Judgement positif seperti yang digambarkan dalam contoh berikut: 
Saya bekerja keras mencari nafkah dengan cara yang jujur.

(I am making an honest living).

Saya bekerja secara berdedikasi, bijak dan kuat.

(I am working dedicatedly, smart \& hard)

Sebagai rumusan, identiti lelaki maskulin yang berjaya dalam pekerjaan dan stabil kewangannya bukan sahaja dipaparkan melalui pekerjaan, pendidikan dan pemilikan objek tetapi juga terbentuk melalui paparan Judgement positif yang memperlihatkan perlakuan dan perasaan mereka terhadap sesuatu pekerjaan.

\subsection{Lelaki yang Sihat dan Atletik}

Sifat maskulin lazim dikaitkan dengan kualiti seperti kekuatan atau keyakinan. Analisis data lelaki menunjukkan kekerapan paparan kekuatan fizikal yang direalisasikan melalui aktiviti riadah yang berkaitan dengan kecekapan dan penguasaan. Berikut ini adalah contoh ciri ini:

Saya banyak terlibat dalam aktiviti rekreasi luar.

(I engage a lot in outdoor activities)

Tahun lepas, saya pergi ke acara rali basikal di sekitar Singapura

(Last year i went for bike rally event that cycling around Singapore)

Terdapat prosodi emosi positif yang direalisasikan melalui ungkapan afektif seperti like (gemar), love (suka) dan enjoy (minat), yang ditafsirkan sebagai minat yang mendalam terhadap aktiviti sukan. Minat ini bukan sahaja terbentuk melalui aktiviti cergas dan sihat, tetapi ia juga digambarkan sebagai emosi positif terhadap apa sahaja aktiviti sukan yang mereka lakukan.

Saya menggemari seni mempertahankan diri

(I like martial art)

Saya suka berenang, kebanyakan kolam renang di kawasan Lembah Klang telah saya kunjungi.

(I love to swim, most of the swimming pools in Klang Valley area i did pay a visit.)

Apa yang berlaku adalah pengkategorian sosial berdasarkan ekspresi emosi (seperti gemar, suka, minat) terhadap aktiviti sukan. Ini dikenali sebagai gaya hidup sosial (social lifestyle) oleh Van Leeuwen (2008). Menurut beliau bentuk ekspresi seperti ini bersifat sosial kerana mereka bukan sahaja mengekspresikan tafsiran tentang masyarakat dan dunia, tetapi ianya juga satu perkongsian nilai dan sikap dengan individu yang lain. Lelaki maskulin yang cergas dan atletik tidak dapat dipisahkan dari gaya hidup sihat berlandaskan kecekapan dan penguasaan sesuatu aktiviti.

Beberapa kata sifat digunakan sebagai pendahuluan kata nama (premodifiers) untuk mewakili lelaki maskulin yang sihat (cth. fit \& athletic-built). Kenyataan fizikal juga merangkumi pernyataan tinggi dan berat badan secara langsung (cth. I am tall about $178 \mathrm{~cm}$ and weight $73 \mathrm{~kg}$ - Ketinggian saya adalah sekitar $178 \mathrm{~cm}$ dan berat badan adalah sekitar 73kg). Bukti korpus menunjukkan bahawa ketinggian sering disebut oleh 
pengiklan lelaki. Kajian awal iklan peribadi menunjukkan bahawa lelaki yang tinggi lazimnya mendapat respons yang lebih tinggi dari wanita berbanding lelaki rendah (Stulp et al., 2013; Brewer \& Riley, 2009). Respons yang lebih tinggi jelas menunjukkan bahawa ketinggian adalah suatu kualiti yang diidamkan seorang wanita. Oleh itu, padanan kata sifat tinggi dan angka (cth. I am tall about $178 \mathrm{~cm}$ and weight $73 \mathrm{~kg}$ ) bukan sahaja ditafsirkan sebagai ketinggian fizikal, tetapi juga menunjukkan persona lelaki yang diinginkan wanita. Kekerapan ciri ketinggian yang sering disebut dalam data menunjukkan kepekaan sebilangan lelaki terhadap nilai tinggi sifat ini dalam konteks pencarian pasangan, dan melihat ia sebagai satu fitur yang mempermudahkan permulaan interaksi dengan wanita.

Selaras dengan hasil kajian lepas mengenai identiti gender (Morettini 2016; Messerschmidt, 2019), dapatan kajian ini menunjukkan bahawa representasi stereotaip maskuliniti kerap digambarkan dalam iklan lelaki. Deskripsi sering tertumpu kepada kestabilan pekerjaan, kekuatan kewangan dan juga penampilan fizikal, seterusnya membentuk dua gambaran yang selaras dengan maskuliniti hegemonik kejayaan dan kekuatan fizikal.

\subsection{Femininiti dalam Ruang Iklan Peribadi Malaysia}

Secara keseluruhan, pola fitur linguistik mewujudkan dua jenis identiti feminin berdasarkan 1) Affect positif (cth. seorang yang penyayang atau a loving person) 2) penilaian Judgement positif (cth. pintar atau intelligent dan rajin atau hardworking). Dari kombinasi pola ini, dua jenis identiti feminin dominan yang terbentuk dalam data wanita adalah 1) wanita penyayang dan 2) wanita cemerlang dan berjaya.

\subsubsection{Wanita Penyayang}

Kepercayaan stereotaip identiti feminin menjangkakan perlakuan dan sikap yang submisif dan pengasih dan paparan nilai moral yang lebih tinggi dikalangan wanita daripada lelaki (Kray et al., 2017). Secara umumnya, dapatan kajian ini menunjukkan kekerapan tinggi sifat pengasih dan ekspresi emosi dalam data wanita. Ciri-ciri ini membentuk representasi identiti feminin hegemonik, wanita penyayang (Bordo, 1999). Wanita penyayang terbentuk melalui ekspresi Affect positif yang merangkumi deskripsi tindakbalas atau keadaan emosi seseorang seperti loving (penyayang), jovial (riang) dan cheerful (ceria) seperti contoh di bawah.

I am caring, jovial, friendly, passionate, very loving.

(Saya penyayang, riang, peramah, bersemangat, sangat penyayang.)

I am romantic...i love being close and affectionate.

(Saya seorang yang romantis ... saya suka menjadi rapat dan penyayang)

Perkataan passionate (bersemangat) terdapat dalam kedua-dua korpus, meskipun empat kali lebih kerap dalam data wanita berbanding lelaki. Terdapat perbezaan penggunaan yang ketara antara gender. Passionate lazimnya digunakan oleh lelaki sebagai perasaan afektif yang ditujukan kepada pekerjaan (cth. passionate about my work - bersemangat terhadap pekerjaan saya) dan perkara yang dilakukan; manakala wanita menggunakannya untuk menggambarkan tingkah laku dan perasaan mereka (cth. I am a passionate woman - Saya seorang wanita yang bersemangat). Walau bagaimanapun, apabila passionate ditujukan ke arah suatu fenomena, ia lebih cenderung kepada kata 
nama yang abstrak, misalnya sebuah minat (cth. passionate about dance - sangat berminat dengan tarian), agama (cth. passionate about serving God - bersemangat dalam menjalankan tanggujawab terhadap Tuhan) dan kehidupan (cth. passionate about life). Secara keseluruhan, penggunaan yang lebih kerap di kalangan pengiklan wanita menggambarkan semangat atau minat mereka yang tinggi terhadap sesuatu perkara.

Kasih sayang juga kerap ditunjukkan melalui penggunaan kata kerja love (suka). Struktur I love (saya suka) merangkumi hampir 30\% daripada semua klausa yang terdapat dalam korpus wanita berbanding 13\% korpus lelaki. Dari segi semantik dan kolokasi, terdapat 55 contoh kebahagiaan terhadap seseorang, aktiviti santai dan aktiviti intelektual, seperti yang ditunjukkan dalam contoh berikut.

Saya suka pergi ke pantai.

(I love going to the beach.)

Saya juga suka belajar dan memperbaiki diri.

(I also love learning and self improvement.)

Saya sangat menyayangi rakan dan anjing saya!

(I do love my friends and dogs a lot!)

Orang merangkumi 12\% daripada objek yang dikasihi (cth. family, friend \& you keluarga, rakan, anda). Me (saya) juga digunakan tetapi ia menjadi sebahagian daripada penyataan kemahuan pengiklan (misalnya I wanted to have a guy who can love me - saya ingin seorang lelaki yang boleh mencintai saya).

Selaras dengan hasil kajian lepas mengenai iklan peribadi, stereotaip femininiti bersifat mesra dan pengasih kerap diperlihatkan oleh pengiklan wanita melalui ekspresi Affect positif.

\subsubsection{Wanita Cemerlang dan Berjaya}

Representasi wanita cemerlang dan berjaya digambarkan melalui kekerapan fitur ketegasan dan sifat berdikari. Berbanding dengan naratif kasih sayang, wanita cemerlang digambarkan melalui kualiti sosial-psikologikal dan Judgement positif (cth. agresif dan bijak) melalui aktiviti dan peranan pekerjaan, pencapaian pendidikan dan kepuasan dalam melakukan aktiviti santai.

Fungsionalisasi pekerjaan dan pendidikan kerap diungkapkan dalam iklan. Wanita cemerlang digambarkan sebagai pelaku aktiviti pekerjaan dan pencapaian cemerlang adalah berdasarkan usahanya sendiri, seperti yang ditunjukkan dalam contoh berikut.

I am a dance instructor/dancer/ choreographer/rhythmic gymnastics coach

(Saya ialah seorang jurulatih tarian/penari/koreografer/jurulatih gimnastik

berirama)

I'm managing the company's branding and marketing communications efforts 
(Saya menguruskan penjenamaan dan usaha komunikasi pemasaran syarikat)

Representasi wanita cemerlang dan berjaya juga direalisasikan melalui kata sifat sosialpsikologikal yang mencerminkan kebolehan dan kemampuan mental dan fizikal individu tersebut, seperti contoh di bawah,

I am intelligent, inquisitive and optimistic

(Saya pintar, bersifat ingin tahu dan optimis)

I am responsible, energetic, independent, outgoing and selfmotivated person

(Saya bertanggungjawab, bertenaga, berdikari, bersikap terbuka dan bermotivasi kendiri)

Judgement positif seterusnya dikaitkan dengan pencapaian pendidikan melalui penggunaan wacana literasi dan pendidikan. Sekiranya kejayaan lelaki digambarkan melalui hak milik intelektual (cth. I have an MBA - Saya mempunyai Sarjana MBA), pengiklan wanita lebih cenderung untuk melihat pencapaian sebagai sebuah pengalaman yang berorientasikan proses, dan bukan sebagai objek hak milik, seperti yang ditunjukkan dalam contoh berikut.

I took a double major in International Studies and Communications \& Media

(Saya mengambil dua jurusan utama dalam Pengajian Antarabangsa dan Komunikasi \& Media.)

I have also completed my MBA.

(Saya juga telah menamatkan pengajian Sarjana dalam Pentadbiran Perniagaan)

Selain aktiviti di atas, para wanita juga meluahkan emosi positif mereka terhadap pengalaman dan pengetahuan dalam pendidikan dan juga terhadap pekerjaan dan aktiviti intelektual, seperti contoh berikut.

I love exploring the world of ideas.

(Saya suka meneroka dunia idea.)

I love what I do and am hungry for more opportunities.

(Saya suka apa yang saya lakukan dan saya inginkan lebih banyak peluang.)

Woods (2007) menekankan sebuah tema dalam wacana wanita yang menggambarkan sifat feminin mereka. Tema ini menunjukkan keupayaan untuk menjadi 'wanita yang hebat'. Untuk menjadi seorang wanita yang hebat, adalah tidak mencukupi dengan hanya mempunyai sebuah kerjaya; seseorang itu juga mesti pakar dalam kemahiran lain seperti mengurus rumah tangga, berhibur dan memelihara hubungan interpersonal. Oleh itu dalam konteks agensi, kehebatan ditafsirkan sebagai kebolehan membuat pelbagai tugas. Agensi difahami sebagai keupayaan autonomi dan kawalan terhadap hidup seseorang (Woodward, 2004). Agensi pelaku ditunjukkan melalui pelbagai frasa kata kerja dalam contoh di bawah. 
Someday i plan to quit my job, open my own cafe/bookstore so I can do the two things $i$ love at the same time.

(Suatu hari saya merancang untuk berhenti kerja, membuka kafe/kedai buku supaya saya boleh melakukan dua perkara yang saya gemari pada masa yang sama.)

\section{Besides working, I am also doing my doctorate of business administration in Multimedia University.}

(Selain bekerja, saya juga mengikuti pengajian ijazah kedoktoran dalam pentadbiran perniagaan di Universiti Multimedia.)

Perbincangan seterusnya beralih kepada representasi identiti Malaysia yang unik berdasarkan kelompok sifat, tingkah laku dan fitur penilaian Judgement positif - iaitu a simple person atau seorang yang sederhana.

\subsection{Representasi I am a simple person}

Penggunaan kata sifat simple (sederhana) kerap digunakan oleh para pengiklan dalam deskripsi identiti mereka, seterusnya menyamai dapatan kajian konstruksi identiti remaja dalam iklan peribadi di Malaysia (Bahiyah \& Kesumawati, 2010). Lebih menarik, analisis simple menunjukkan bahawa lebih banyak wanita (berjumlah 30) berbanding lelaki (berjumlah 20) menggunakan kata sifat ini dalam gambaran identiti mereka.

Perkataan yang dipilih oleh pengiklan dalam representasi identiti mereka, memperlihatkan nilai positif sesuatu konsep (cth. ketinggian dan kecantikan) dalam proses pemilihan pasangan. Dapatan kajian menunjukkan bahawa kita lebih cenderung untuk memilih pasangan yang memiliki nilai moral atau minat yang sama, kerana persamaan adalah satu konsep penting dalam hubungan interpersonal (Swami, 2017; Jarrett, 2018). Frasa 'a simple gal' atau 'a simple guy' boleh dilihat sebagai gabungan klasifikasi gender dan ekspresi ATTITUDE yang boleh menjajarkan mereka secara serentak di my.match.com.

Simple dalam data kajian ini membawa maksud seorang yang sederhana dari segi perlakuan dan gaya hidup yang boleh diklasifikasikan sebagai satu penilaian Judgement yang positif. Dalam beberapa contoh di bawah, perlakuan simple digambarkan melalui cara kehidupan yang praktikal dan mencukupi dengan hanya keperluan asas. Kata sifat ini menunjukkan kawalan nafsu terhadap kemahuan dan gaya hidup yang berlebihan.

Really a simple person at heart - I choose to focus on just a few basic needs.

(Benar-benar seorang yang sederhana di hati - saya memilih untuk menumpukan perhatian kepada beberapa keperluan asas.)

I am just a simple guy who own a simple life style and easy to deal with. (Saya hanyalah seorang lelaki sederhana yang memiliki gaya hidup yang sederhana dan senang diurus.)

Analisis juga menunjukkan simple berkolokasi dengan leksikal yang menggambarkan Affect positif (cth. caring) dan Judgement positif seperti open-minded (berfikiran terbuka), friendly (peramah), laugh (ketawa), jokes (jenaka) dan easy going (ramah), 
yang seterusnya mewujudkan satu aura positif dalam data (Baker et al., 2008). Berikut adalah contoh 'simple' dan kolokasinya dalam data.

I'm just a simple person... An optimistic, happy go lucky \& cheerful type of person. Likes to smile.

(Saya seorang yang sederhana... Seorang yang optimis, periang \& ceria. Suka senyum.)

I'm just a simple guy who is easy going, caring and understanding.

(Saya seorang lelaki sederhana yang peramah, mengambil berat dan memahami.)

Penggunaan 'simple' yang berulang-ulang dalam data, menjadikan individu simple sebagai satu konstruksi identiti Malaysia yang tipikal dan lazim dalam korpus pengiklan Malaysia. Yang jelas, kekerapan kata simple itu sendiri merupakan indikasi nilainya yang positif dalam konteks pencarian jodoh di Malaysia. Sebagai satu representasi identiti Malaysia yang unik dan tipikal, frasa a simple guy/gal/person padat dengan nilai interpersonal yang membentuk ikatan antara individu yang sedang mencari pasangan hidup.

Kajian ini telah menunjukkan cara-cara perkaedahan kuantitatif dan kualitatif yang membantu dalam mengenal pasti pola dan interaksi fitur linguistik (cth. penyataan-I, kata nama dan kata sifat) dan ekspresi ATTITUDE yang digunakan dalam konstruksi identiti gender. Dapatan kajian menunjukkan persamaan dengan penemuan kajian awal menerusi pembentukan identiti maskulin dominan 1) Lelaki berjaya dan stabil kewangan 2) Lelaki sihat dan atletik, identiti feminin 1) Wanita penyayang dan 2) Wanita Cemerlang dan Berjaya. Lebih menarik adalah penemuan identiti individu Malaysia sebagai 'a simple person' yang kerap dalam data. Hasil dapatan juga menunjukkan bahawa representasi identiti feminin, maskulin dan Malaysia bukan hanya terbentuk melalui pengkategorian identiti, tetapi juga melalui penilaian terhadap tingkah laku, sifat, emosi dan minat seseorang individu. Dengan ini, apa yang dapat dirumuskan secara empirikalnya adalah konsep identiti sebagai satu bentuk persembahan diskursif, yang mana identiti gender bukanlah suatu sifat yang intrinsik atau semula jadi secara biologi, tetapi ianya terbentuk melalui pengulangan perlakuan, penyataan, ungkapan perasaan dan proses pemikiran setiap individu. Seperti yang dinyatakan oleh Butler (1996):

"There is no gender identity behind the expressions of gender... identity is performatively constituted by the very 'expressions' that are said to be its results". Butler (1996, ms 25)

\section{Kesimpulan}

Gabungan kerangka pengkategorian Pelaku Sosial, ATTITUDE dan teknik korpus linguistik yang digunakan dalam kajian ini digunakan dalam usaha mencari ekspresi performatif (Butler, 1996) identiti gender dalam iklan peribadi dalam talian. Pola lazim yang membentuk representasi identiti gender yang tipikal dan tidak tipikal melalui perbandingan jenis struktur dan semantik-wacana melalui analisis penyataan- $I$ dan kumpulan nominal. Analisis terperinci fitur linguistik telah menunjukkan bagaimana identiti tekstual dikendalikan berdasarkan tuntutan genre dan juga permintaan interpersonal dalam pencarian pasangan hidup. Dari perspektif konstruksionis sosial, 
gandingan sumber pengkategorian Pelaku Sosial dan sumber interpersonal ATTITUDE menunjukkan identiti sebagai satu kewujudan diskursif. Interaksi pelbagai perlakuan dan penilaian diri serta objek melalui kata nama, kata sifat dan penyataan-I, menghasilkan pelbagai persembahan holistik identiti yang berunsur tipikal (atau stereotaip), tidak tipikal (kaunter-stereotaip) dan unik. Kajian ini merupakan sumbangan kepada para sarjana dalam bidang identiti, gender dan linguistik dalam objektif mengenal pasti representasi femininiti, maskuliniti melalui interaksi ciri-ciri linguistik menggunakan pendekatan kuantitatif dan kualitatif berasaskan korpus dalam kajian teks iklan peribadi.

\section{Penghargaan (Acknowledgement)}

Terima kasih kepada Prof. James Martin dan Dr. Alexis Don yang banyak memberi komen dan cadangan yang membina dalam penulisan makalah ini.

\section{Kewangan (Funding)}

Kajian dan penerbitan ini tidak menerima sebarang tajaan atau bantuan kewangan.

\section{Konflik Kepentingan (Conflict of Interests)}

Penulis tidak mempunyai sebarang konflik kepentingan.

\section{Rujukan}

Aboim, S. (2016). Plural Masculinities: The Remaking of the Self in Private Life. Oxon. Routledge.

Bahiyah A. H., \& Kesumawati A. B. (2007). Glocalisation of personal ads - gender identity construction of Malaysia adolescents. Jurnal Komunikasi, 23, 41-56.

Baker, P. (2003). No effeminates please: A corpus- based analysis of masculinity via personal adverts in Gay News/Times 1973-2000. In Benwell, B. (Ed). Masculinity and men's lifestyle magazines. Blackwell. Oxford.

Baker, P. (2006). Public Discourses of Gay Men. Oxon. Routledge.

Baker, P. (2008). Sexed Texts: Language, Gender and Sexuality. London: Equinox.

Baker, P., Gabrielatos, C., Khosravinik, M., Krzyzanowski, M., McEnery, T., \& Wodak, R. (2008). A useful methodological synergy? Combining critical discourse analysis and corpus linguistics to examine discourses of refugees and asylum seekers in the UK press. Discourse \& Society, 19(3), 273-306.

Baker, P. (2009). Contemporary Corpus Linguistics. London: Continuum.

Benwell, B., \& Stokoe, E. (2006). Discourse and identity. Edinburgh: Edinburgh University Press.

Bordo, S. (1999). The male body: A new look at men in public and private. New York: Farrar, Straus and Giroux.

Brewer, G. \& Riley, C. (2009). Height, Relationship Satisfaction, Jealousy, and Mate Retention. Evolutionary Psychology, 7(3).

Bruthiaux, P. (1994). Me Tarzan, You Jane: linguistic simplification in "personal ads" register. In Biber and Finegan (1994a), 136-54.

Butler, J. (1990). Gender trouble: Feminism and the subversion of identity. New York: Routledge. 
Butler, J. (1996). Gender as Performance. In P. Osborne (Ed.), A Critical Sense: Interviews with Intellectuals (pp. 108-125). London: Routledge.

Cameron, C., Oskamp, S. and Sparks, W. (1977). Courtship American style: Newspaper ads. Family Coordinator, 26(1), 27-30. http://dx.doi.org/10.2307/581857

Connell, R. W., \& Messerschmidt, J. W. (2005). Hegemonic masculinity: Rethinking the concept. Gender and Society, 19(6), 829-859.

Coupland, J., (1996). Dating advertisements: discourses of the commodified self. Discourse and Society, 7(2), 187-207.

Downing, L. (2013). "Safewording! Kinkphobia and Gender Normativity in Fifty Shades of Grey." Psychology and Sexuality, 4(1), 92- 10.

Dunn, M. J., Brinton, S., \& Clark, L. (2010). Universal sex differences in online advertisers age preferences: Comparing data from 14 cultures and 2 religious groups. Evolution and Human Behavior, 31(6), 383-393.

Fong, Y. L., \& Nyathi, S. E. C. (2019). Gender Representation and Framing of Malaysian Women: A Study of Feature Articles in Female Magazine. Journal of Content, Community and Communication, 10(9), 29-38.

Gama e Silva, B. (2007). The Object of Virtual Desire: seducing on the Internet. Retrieved on Aug 3, 2010 from http://www.unigranrio.br.

García-Gómez, A. (2020). Discursive representation of masculinity and femininity in Tinder and Grindr: Hegemonic masculinity, feminine devaluation and femmephobia. Discourse \& Society, 1(4), 390-410

Gilles E., Starbuck, C. L. (2018). Exceptional intelligence and easygoingness may hurt your prospects: Threshold effects for rated mate characteristics. British Journal of Psychology, 110(1), 151-172

Hashim, R. S., Yusof, N. M., Hamdan, S. I., \& Raihanah, M. M. (2011). Rethinking Malaysian perspectives of gender constructions through ethnographic-oriented approach. Procedia-Social and Behavioral Sciences, 18, 420-426.

Jarrett, C. (2018). Is it better to be like your partner? At https://www.bbc.com/future/article/20181011-are-relationships-better-ifpartners-are-more-similar

Kesumawati A. B. (2015). Identity in Online Personal Ads: A Multimodal Investigation. Asian Social Science, 11(15), 313.

Kesumawati, A. B. (2014). 'A (Sensitive New Age Guy) with Difference': Gendered Performances in Online Personal Advertisements. Linguistics and the Human Sciences, 9(1), 5-34.

Kesumawati A. B. (2016). Courtship Initiation Behaviour in Online Personals. Asian Social Science, 12(7).

Kim, S. \& Y. Lee. (2018). Why do women want to be beautiful? A qualitative study proposing a new "human beauty values" concept. PLOS ONE, 13(8), e0201347.https://doi.org/10.1371/journal.pone.0201347

Kray, L., Kennedy J. \& Ku G. (2017). Are Women More Ethical Than Men?. At https://greatergood.berkeley.edu

Lippa, R. (2007). The preferred traits of mates in a cross-national study of heterosexual and homosexual men and women: An examination of biological and cultural influences. Archives of Sexual Behaviour, 36(2), 193-208.

Marley, C. (2000). Beyond the usual: The modification of gender in a British dating ads column. Text-Interdisciplinary Journal for the Study of Discourse, 20(3), 271-306.

Martin, J. R., \& White, P. R. R. (2005). The language of Evaluation: Palgrave Macmillan Basingstoke.

Messerschmidt, J. W. (2019). The Salience of "Hegemonic Masculinity". Men and Masculinities, 22(1), 85-91. 
Morettini F. M. (2016). Hegemonic Masculinity: How the Dominant Man subjugates other Men, Women and Society. At https://www.globalpolicyjournal.com/blog/27/10/2016/hegemonic-masculinityhow-dominant-man-subjugates-other-men-women-and-society

O’Donnell, M. (2008). UAM Corpus Tool. Madrid.

Parker, K. \& Stepler, R. (2017). Americans see men as the financial providers, even as women's contributions grow. At https://www.pewresearch.org/facttank/2017/09/20/americans-see-men-as-the-financial-providers-even-aswomens-contributions-grow/

Radzi, N. S. M., Bakar, K. A., Hamid, A., \& Dato'Hj, B. (2021). Negotiating Alternative Masculinities in Men's Magazines: Transitivity in the Formation of Counter Hegemonic Identities. GEMA Online Journal of Language Studies, 21(2).

Radzi, N. S. M., Hamid, B. D. H. A., \& Bakar, K. A. (2018). The discursive construction of modern masculine identities in contemporary Malaysia. GEMA Online Journal of Language Studies, 18(3).

Scott, M. (2004). WordSmith Tools version 4. Oxford: Oxford University Press.

Shalom, C. (1997). That great supermarket of desire: attributes of the desired other in personal advertisements. In Harvey, K., \& Shalom, C. (Eds.), Language and Desire: encoding sex, romance and intimacy. London: Routledge.

Stets, J. E., \& Burke, P. J. (2000). Femininity/ masculinity. Encyclopedia of Sociology, Revised Edition (pp. 997-1005). New York: Macmillan.

Stulp, G., Buunk, A. P. \& V.Pollet T. (2013). Women want taller men more than men want shorter women. Personality and Individual Differences, 54(8), 877-883.

Swami, V. (2017). Most of us tend to be attracted to people who are similar to ourselves by The Conversation. Social Psychology https://www.psypost.org/2017/03/ustend-attracted-people-similar-48596

Tajfel, H., \& Turner, J. C. (2004). The Social Identity Theory of Intergroup Behavior. In J. T.

Thébaud, S. (2010). Masculinity, Bargaining, And Breadwinning: Understanding Men's Housework in the Cultural Context of Paid Work. Sage Publications. Gender and Society, 24(3), 330-354.

Van Leeuwen, T. (2008). Discourse and practice: New tools for critical discourse analysis. Oxford: Oxford University Press.

VanderStouwe, C. (2019). 'Straight-ish': agency, constraints, and the linguistic negotiation of identity and desire in online personal advertisements among men seeking men. Gender and Language, 13(1), 122-145. https://doi.org/10.1558/genl.30939

Williams, T. L. R. (2007). The textual construction of femininity if women's fitness magazines. (Unpublished thesis dissertation). University of Texas.

Woods, J. T. (2007). Gendered Lives: Communication, Gender, and Culture (Eighth Edition). Boston: Wadsworth.

Woodward, K. (Ed.) (2004). Questions of Identity. London: Routledge. 